Article

\title{
The American Jewish Future after Immigration and Ethnicity Fade: H. A. Wolfson's Analysis in 1918
}

\author{
Joel Perlmann \\ Levy Economics Institute, Bard College, 30 Campus Rd, Annandale-On-Hudson, NY 12504, USA; \\ perlmann@levy.org
}

Received: 11 October 2018; Accepted: 14 November 2018; Published: 19 November 2018

\begin{abstract}
H. A. Wolfson arrived in the United States at 16 from the Lithuanian region of the Russian Empire and at Harvard as a freshman five years later. He remained at Harvard until his death in 1974, as Emeritus Professor of Hebrew Literature and Philosophy. Among the most important historians of western religious philosophy, he published on contemporary issues only until 1925 and even then only rarely. Nevertheless, his 1918 article, "Pomegranates", deserves attention. Wolfson clearly followed debates about the American ethnic future. He carved out an original and unexpected position on that issue, and on the American Jewish future within that context. He perceptively rejected Horace Kallen's views of a "multi-national America", and like Israel Zangwill's Melting Pot, he stressed that full cultural and political assimilation would occur in the United States. But unlike Zangwill, he argued that Jewish religious creativity would find a long-term place in American life, once freed of its national trappings. Strongly supporting a Hebraic renaissance and a Jewish homeland in Palestine, he also emphasized with great force that the "we"- the east-European Jewish intellectuals and the Zionists—had greatly misunderstood the promise of Reform Judaism for the diaspora.
\end{abstract}

Keywords: American Judaism; melting pot; pluralism; assimilation; Zionism; Yiddish nationalism

Harry Austryn Wolfson died in 1974 at the age of 87, having spent his life since 1908 at Harvard University. He was a towering figure in American scholarship, revered as one of the greatest historians of medieval Jewish, Moslem and Christian philosophy and theology. In the decade and a half prior to 1925 , he also wrote a number of opinion pieces on current Jewish cultural and political affairs, a theme that afterward gave way entirely to his scholarly agenda. In this paper I call attention to the importance of one of these early opinion pieces, "Pomegranates" (Wolfson 1918). When that essay has been discussed at all by historians, it has been primarily to address the rage it vents at "the Yidds", that is camp of Yiddishist, especially socialist, nationalists among the Jewish immigrant community. But the essay actually is a window into the thinking of a brilliant young Jewish intellectual just then turning thirty.

Far from confirming his later reputation as a cloistered intellectual interested only in his scholarly field, Wolfson's essay reveals him as someone who followed American debates about the balance between the persistence of immigrant distinctiveness and the forces of assimilation. He commented on the theme both as a general social issue and as it applied specifically to American Jews. This is historically interesting, inasmuch as it reflects the breadth of his thinking at that time and as a gauge of his underlying self-perception. He explicitly rejected the notional idea of a "multi-national America", (the ideal that later came to be called cultural pluralism and is akin to today's ethnoracial multiculturalism), both as a practical observation and as an ethical desideratum. But his essay offers much more, namely a view of the American Jewish future that is all his own, and one that is unexpected, given the particular nature of his East European Jewish origins and his own earlier intellectual and political loyalties. His position is distinct from those of such influential writers as Israel Zangwill, Judah L. Magnes or Horace M. Kallen. He shares some views with each of these, but self-consciously 
distinguishes his position and witheringly critiques Kallen's and Magnes's in particular. He also presents a remarkably positive view of the Reform movement in Judaism and criticizes the views of Reform that "we"-East-European Jews, Hebraists and Zionists-have held about the movement, even as he is quite clear about the failings of Reform. And finally, if he follows the spiritual Zionist Ahad Ha'am (Asher Ginzberg) in some respects (like Magnes and Kallen), his own view of the American Jewish future and its interaction with a "spiritual center" in the envisioned Jewish homeland in Palestine deviates in clear ways from all three of those writers.

Besides calling attention to the historical importance of Wolfson's paper, I think two features of the paper will resonate especially with readers today. Fittingly, one concerns American ethnic life generally and the other American-Jewish realities. First, Wolfson was familiar with the calls by immigrant and ethnic activists (Jews and others) for cultural autonomy and the end of laws and policies they considered coercive. These calls are far from well-known today, especially in their emphasis on coercion; Wolfson contemptuously reports them. Second, Wolfson was absolutely clear that the future of American Judaism would not be bound up with Jewish ethnic life, that the creation of a Jewish homeland that he so strongly supported would eventually split off Jewish religious and national life in a natural way that could be celebrated. That he made these claims while still in the midst of the mass wave of Jewish immigration from Eastern Europe, leaves the impression that he speaks to us from before an era of ascendant American Jewish ethnicity-speaking, that is, from before the era of the "ethnic church", the direct embrace of ethnicity itself, and the full throated post-World War II support for the Jewish state (Sklare 1955; Glazer 1989; Cohen and Eisen 2000; Wertheimer 2018).

Section 1 of this paper describes Wolfson's early biography and near legendary later reputation, including his reputedly cloistered focus on his scholarship within the confines of Harvard's Widener Library. Section 2 explains and deals with the issue of the rage Wolfson vented on the party of the so-called "Yidds", in order to show that it is best understood in the context of familiar debates at that time between Hebraists and Yiddishists-that is, the Jewish ideological divisions that stressed distinct language strategies for Jewish survival. It also points out how much of Wolfson's Hebraic elitist pose was related to the orientation of the Russian Jewish cultural Zionist, Ahad Ha'am. Section 3 considers the intellectual claims about American ethnic persistence and assimilation during the decade preceding the appearance of "Pomegranates" and indeed how these had brought Henry Hurwitz to suggest a volume on these themes to which he thought Wolfson might contribute. This section takes up in succession the arguments of Israel Zangwill (in The Melting Pot), Judah L. Magnes and Horace M. Kallen. The "Pomegranates" article appeared in two parts, the first in February of 1918 and the second four months later. Sections 4 and 5 respectively deal with each. Abstracted from their specific formulations, the broad arguments of the second installment are not different from those in the first. Nevertheless, it is best to handle the two parts of "Pomegranates" sequentially since Wolfson clearly wrote the second after the first part was published and the specific approaches to themes of ethnic persistence vs. assimilation, intellectual predecessors, and the evaluation of the Reform movement in Judaism all become more explicit and detailed in that second pass. Finally, Section 6 offers concluding remarks.

\section{Wolfson's Origins and Iconic Standing}

For decades Wolfson was a legendary figure: for the enormous range of the sources he had mastered, his breathtakingly novel views of how they should be understood, the great number of his monumental studies, and his clear and graceful writing. Legendary too was his reclusive concentration on his academic subjects (Shenker 1972; Feuer 1976; Wieseltier 1976; Schwarz 1978; Twersky 1978).

Wolfson was born in the Lithuanian area of the Russian Empire, into a family of Hebraists and Zionists. Early on, he was recognized as a prodigy, and by the age of nine began attending a succession of ever-more advanced Yeshivas across the region. Then, when he was sixteen, his family immigrated to the United States. After spending some time in yet another advanced Yeshiva, this time in New York City, he worked as a Hebrew teacher in Scranton, Pennsylvania. While there, he used the opportunity 
to spend a few months in an elementary school and three years in the classical program of the local high school. According to later legend, his performance there was so extraordinary that it was remembered half a century later. At any rate, his performance made him valedictorian. His history teacher insisted (against his own instincts) that his thick East European accent ought not prevent him from giving the usual graduation address, and she worked with him to make it happen. The equally supportive high school principal introduced Wolfson to a recent Jewish alumnus who was just then returning to Scranton after graduating from Harvard College. This young man explained that a poor boy could attend Harvard on a scholarship. Wolfson won such a scholarship, enrolled in 1908, and by 1912 had published a prize-winning essay contrasting the responses of Yehuda Halevi and Maimonides to the Aristotelian legacy. Following his graduation that year, he used a Harvard travel fellowship to study Hebrew manuscripts in the great European archives. He returned to do his PhD work and then joined the Harvard faculty. No position in Hebrew Literature and Philosophy existed at the university, and that remained the case for some years. But he taught there full-time on a salary contributed by well-to-do Jewish leaders. In 1925, a tenured chair was endowed for him (Feuer 1976; Schwarz 1978; Klingenstein 1991). Whatever the level of religious observance practiced during his childhood and youth, at some point he lost the need to adhere to Jewish ritual and prayer, although it appears likely that he continued to feel an emotional connection to occasional religious events. He is supposed to have quipped that he was "a non-observant Orthodox Jew". His personal theological beliefs went unrecorded (Wieseltier 1976; Klingenstein 1991, p. 215).

The image of Wolfson as a reclusive figure referred to his bachelorhood and especially to his research and publication; judging by the testimony of those who knew him, however, reclusiveness was never an accurate view of his conversation and reading. Moreover, his early career aspirations and publications were broader than the reclusive image suggests. Wolfson left behind a corpus of writing from his teens and twenties inspired by his belief in a Hebrew renaissance and Jewish nationalism - poetry and prose, fiction and reportage, in English and Hebrew. But contributions to that corpus were dwindling fast by the early 1920s. By 1925 they had ceased (Feuer 1976; Schwarz 1978).

Nearly all of the articles on contemporary themes that he did publish in the decade after 1915 appeared in The Menorah Journal. The journal first appeared that year as the publication of the Menorah Society, which in turn was an organization begun by a handful of Jewish students at Harvard nearly a decade earlier (it soon spread to numerous other campuses). Wolfson was involved in both the activities of the Society and the Journal. The Journal found an able and energetic lifetime editor in Henry Hurwitz (himself a Harvard alumnus and Wolfson's friend) and it survived into the early 1960s. Its articles often grappled with anti-Semitism, Jewish culture, religion, race, nationalism, Zionism, and assimilation. Its contributors comprise a stellar list of Jewish and non-Jewish intellectuals (Greene 2011; Schwarz 1978). Hurwitz remained Wolfson's lifetime friend and eagerly solicited articles from him during the first decade of the journal.

"Pomegranates" appeared during the last year of World War I, the first of two installments about eight months after the United States joined the conflict and about three after the Balfour Declaration announced British support for a Jewish homeland in Palestine. The essay is a series of loosely-connected sections, each a page or two or three in length, offering trenchant comments on contemporary developments.

\section{On "The Yidds"}

So trenchant were the essay's comments that Wolfson and Hurwitz agreed that it be published under a pseudonym and with the following disclaimer.

The boldness of some of the ... views expressed ... makes it desirable to remind our readers that the MENORAH JOURNAL is an open forum ... for the expression of opinions to which 
neither the JOURNAL nor the Intercollegiate Menorah Society is in any way committed". (Wolfson 1918, p. 16) ${ }^{1}$

Any understanding of "Pomegranates" must begin with Wolfson's furious attack on those whom he dubbed "the Yidds". This attack was one central theme of the essay, but not, I think, its most interesting part, when reading it retrospectively a century later. Nevertheless, it is best to begin with this theme to avoid being diverted by it, especially since most of the slight attention historians have given the essay has been in the service of explaining the author's fury (Schwarz 1978, pp. 60-63, 151; Goldberg 1989, pp. 44-46; Klingenstein 1991, pp. 32-33; Greene 2011, pp. 127-31). This attention seems to be driven by the seeming paradox that one so steeped in the world of East European Jewry could dismiss the claims for Yiddish culture with such force and apparent anger. A careful answer to that question will indeed be relevant to the historical value retained by the essay today.

Wolfson's criticism of "the Yidds" may have been unusually strong but it was part of a then-familiar (and vociferous) cultural and political struggle between partisans of the two Jewish languages. Wolfson's position was a variant of the Hebraists' position in their debate with the Yiddishists. For Wolfson, as for many others on both sides of the struggle, far more than the glorification of the Hebrew language at the expense of Yiddish was at stake. This debate had its roots in the variant of the Jewish "enlightenment" (Haskalah) that took root in the Russian Empire in the nineteenth century, and particularly by educators and propagandists for that movement (Maskilim). More specifically, Wolfson grappled with the ideas of the circle around the leading cultural Zionist writer, Asher Ginsberg, commonly known by his pen-name, Ahad Ha'am (Zipperstein 1993). Nevertheless, the extraordinary spleen that Wolfson vented against his ideological adversaries, his references to American issues, and the emphasis on the particular moment at which he wrote were unique to him and to this essay.

At issue were two very different evaluations of the historical legacy of the Jewish people and also of the tensions between the masses and intellectual elites. For the Yiddishists, who were partisans of the language of the "common folk masses", the inherited, classical Hebraism of the rabbis and its vaunted re-adoption by modern Zionists was moribund and bound to remain limited to small elites. It was easy, also, to link the Yiddishist position to socialist thought, to claim the moral high ground in favor of social equality and the championing of the masses over a self-serving bourgeoisie.

Wolfson would have none of this; he was an unapologetic elitist. To begin with the link the Yiddishists made between the homespun, everyday vernacular and socialist redress in the name of equality, he rejected these claims as a masked demand for undeserved status and power by the weak and "degenerate" (Wolfson 1918, pp. 17-20). This argument had more than a whiff of Nietzsche's theory of ressentiment about it, perhaps also of ad hominem psychologizing (Wolfson 1918, p. 25). But Wolfson's deeper purpose was to claim the right of the intellectually "able" to ponder anew the real legacy of Jewish history. For this reason "Pomegranates" begins with a section titled "The 'Selfishness' of the Menorah [Society members]" (Wolfson 1918, p. 16). Serious Jewish students at elite colleges had every moral right to spend their colleges years thinking through important issues, rejecting any condemnation that they were only thinking and not yet throwing themselves fully into the political struggles of their times, or into charitable social welfare on behalf of the impoverished Jewish masses.

Nor (he argued) were Hebraism and the elite traditions of Jewish learning (represented by the well-schooled rabbis) best understood as the intellectual arm of a Jewish bourgeoisie exploiting the Jewish worker. It was, rather, the culture of Yiddish and the Yiddishist leaders that required the critical attention of social and historical analysis, so as to lay bare the questionable character of their enterprise. For centuries, Wolfson pointed out, the Jews of Eastern Europe had endured cultural and political isolation and increasing impoverishment under the region's backward regimes. This situation continued a century and more after gradual Jewish emancipation had begun in Western Europe and

1 The editors revealed Wolfson as the author three years later when he published a last paper in the Menorah Journal (Wolfson 1921). 
the United States. When some form of emancipation had finally come to the Jews of Eastern Europe, it came abruptly. One result was a Yiddishist ideology which emphasized only the most recent and only the most egregiously plebeian characteristics of the Jewish masses. This ideology had nothing in common with the attempts in the modern West to create a meaningful synthesis of the authentic Jewish legacy with modern thought. Indeed Wolfson supported these latter attempts at synthesis with the same degree of emotional condemnation he hurled at the Yiddishist ideology.

He saw the positive attempts at synthesis as the contemporary heirs of the great work of Jewish elite intellectuals over many centuries. It was not only the elite intellectual identity of the synthesizers but also, of course, the authenticity of the legacy they grappled with that made these efforts so positive for Wolfson. This legacy reflected the stages through which ancient Judaism had unevenly and imperfectly evolved over many centuries in tension with the wider intellectual advances in Europe and the middle east. These advances involved legal commentary on Biblical commandments as well as theology and philosophy generally. They also involved transformations of prayer and ritual. Creative syntheses emerged from these tensions especially in relatively favorable social, economic and political conditions, which allowed the Jews to look outward.

The masses of the Yiddish-speaking Jewish poor were not Wolfson's real target. True, he forcefully rejected the socialist-tinged, romanticized view of their existence and culture: "filthy, pestilential and unwholesome in the subterranean sewerages of European letters" (Wolfson 1918, p. 20). Nevertheless, Wolfson seems to say, the same could be said for any proletarian culture; it only requires comment because misguided Yiddishist leaders glorify that culture and find it to be the most authentic Jewish heritage because it emerges in the most isolated conditions of Jewish life.

For Wolfson these themes needed the strongest possible enunciation precisely in the months when "Pomegranates" was composed, for the British conquest of Palestine (then in progress) and their Balfour Declaration 2 November 1917) had transformed the stakes at issue. Wolfson detected a sudden Yiddishist interest in the Palestine project. Until the Balfour Declaration, they had limited their interests to Jewish conditions in Eastern Europe and in the great Western cities to which the Jewish masses had been immigrating. But now "the Yidds" seemed eager to claim the Jewish settlement of Palestine, too. And since the common people raised on Yiddish greatly outnumbered the Hebraists, this new Yiddish interest in transforming the Palestine venture was a serious matter (Wolfson 1918, pp. 23-24). The conflict he hinted at here was between the culture of a discerning elite and the rule of the mob.

So many of these arguments were familiar from the Ahad Ha'am circle and from Russian Jewish Hebraists generally: the insistence on what was of genuine value in the Jewish historical legacy, the centrality of national and religious transformations through the Hebrew revival, the self-proclaimed role of the enlightened, outward-looking intellectual elite in that revival, the mistrust of the ignorant masses and of the Yiddishist leaders' claims to the authenticity of those masses and calls for privileging social equality over the Hebraic cultural revival (Zipperstein 1993, pp. 35-49, 68-83, 91-94, 147-48). We will soon see that Wolfson, in formulating his own unique views on the American Jewish future, also incorporated another of Ahad Ha'am's key conceptions: a "spiritual center" created by the Zionists in Palestine that would reinvigorate diaspora Jewish communities. If we wish to find those intellectual roots of "Pomegranates" that did not come from his reading on issues of American immigration and assimilation but from Jewish cultural origins, we would do well to focus on the ideals and concerns of the Hebrew Haskalah and Ahad Ha'am, with a special receptivity, perhaps, to their elitist nuances. His formulations were hardly limited to those he found in Ahad Ha'am, but he surely grappled with that writer as he sought his own. Still farther back, Wolfson's earliest 'Litvak' 'Mitnagid' origins and studies (that put its faith in reasoned, incisive argument by the sharpest minds) would have predisposed him to such an approach (Klingenstein 1991, p. 23). Later, his interpretation of Harvard's best features-to say nothing of his fascination with the greatest religious thinkers from Philo to Spinoza-reinforced this approach. 
"Pomegranates" was widely praised when it appeared-at least by the small group of intellectually-oriented readers of the Menorah Journal. Hurwitz was ecstatic with the piece, and reported to Wolfson that others had written to say it was the best thing to appear in The Menorah Journal thus far (that is, in its four years of publication; Hurwitz 1918). Horace Kallen, who knew the author's identity, wrote to congratulate Wolfson and told him he agreed entirely with the critique of the "Yidds", but that he thought perhaps it was too angry to win supporters, and that it would be best at present not to alienate more people than necessary (Kallen 1918). Finally, if we must find a psychological reason for the degree of rage Wolfson showed, best to seek it, I think, in his exasperation with the anti-intellectualism he perceived in the opposition and in the need for a stand in the particular historical moment. ${ }^{2}$

\section{Hurwitz's Invitation to Wolfson, and the Intellectual Context, 1908-1917}

On 10 July 1917, Hurwitz wrote to Wolfson about a new idea for a publication.

I am driven now by the idea of getting out a volume of articles on the general subject of "Democracy and the Melting Pot" with particular reference to the place of the Jew in the American Commonwealth". We could reprint a number of papers from the Journal, e.g., those By Brandeis, Kallen, Randolph Bourne; and try to get other papers ... by Max Eastman, John Dewey, Harold Laski, yourself, Alfred Zimmern, Walter Lippmann ... Stearns, Francis Hackett. Don't you think such a book would be a valuable stimulant to thinking on the whole question, both for Jews and for non-Jews? (Hurwitz 1917a)

This was an impressive range of authors indeed, and most of them had already contributed to the Menorah Journal or would do so during the next three years. Hurwitz's conception was for an intervention into a live and current discussion among Americans.

Wolfson replied enthusiastically, if perhaps shifting the weighting among the themes Hurwitz had mentioned. "Your idea about publishing a volume on current Jewish problems is an excellent one. I have been working for some time on a paper; and if I . . succeed to bring it to a happy ending, I will send it to you" (Wolfson 1917a). He seems to have sent a first draft of a piece entitled, "The Jews and Multi-National Americanism" in early November (Hurwitz 1917b). It would eventually become the fifth section of the "Pomegranates" article, "Zionism and Multi-National Americanism. Perhaps the narrowing of the theme implied by the change in title served as a goad for Wolfson to return to these issues in the second part of "Pomegranates", which opens with the equally remarkable ninth section, "The Cephalic Index and Baseball" (Wolfson 1918, pp. 20-23, 162-63).

The two parts of the essay included 13 sections that could seem to be only loosely connected. Indeed, both he and his editor initially thought of the sections as "editorials" that could stand alone or as part of a coherent single article (Wolfson 1917b). And yet eventually, when the writing was far along and Hurwitz suggested that perhaps the sections still could be treated as independent editorials, Wolfson stressed that they were mutually dependent and should come together (Hurwitz 1917c; Wolfson 1917c).

As Hurwitz's letter shows, Wolfson was hardly writing in a vacuum. For a long time, two contrary views of immigration policy struggled for supremacy - praise for America's role in absorbing immigrants and concerns that it took in too many. Related to the latter view were fears about urban immigrant ghettos of poverty, crime and disease. In addition, the new immigrant influx also seemed to threaten American values because so many of the new arrivals knew nothing of democratic life and republican institutions. A great deal seemed to turn on the nature of America's assimilative

2 Today, a different feature of the article would also draw the reader's discomfort and bemusement. The concluding section of "Pomegranates", pt. 1 titled "Three daughters of the same race" (pp. 25-26) and a section of "Escaping Judaism", pt. 2 titled "The Legend of Imogen" (pp. 163-65) describe women who appear intellectually shallow or limited and especially likely to make foolish choices about Jewish life. 
powers: would its economy and culture succeed in quickly overcoming immigrant heterogeneity? An important added concern was wrapped up in the racial theories of the time that viewed immigrant cultural as expressions of biological differences, that racial differences made the triumph of assimilative forces dubious.

Such concerns about the immigrants had led, after a quarter-century of political struggles, to immigration restriction. By the time America went to war in 1917, and roughly when Hurwitz first wrote to Wolfson about his new idea for a book of essays, Congress finally barred illiterate immigrants. Much more stringent restrictions, based on national and ethnic origins, would be passed just a few years later (the "Quota Acts" of 1921 and 1924). In the years between 1910 and 1920, indeed, it was impossible for a reflective person not to wonder about how the great waves of immigration would determine the future of American culture and the outlooks of immigrant descendants (Higham 1955; Zolberg 2006).

Notable Jewish authors were central to both the defense of the immigrants in general and to the formulations of arguments about immigrant and ethnic influence on the American future. Not coincidently, of course, the relevant debates also involved Jewish writers' thinking about the future of American Jewish culture in particular. Perhaps the most well-known push-back against the fears about immigration had come nearly a decade before Wolfson wrote, in Israel Zangwill's 1908 play, The Melting Pot. For Zangwill, whatever powers racial origins held over character, American assimilative forces would ultimately prove much stronger.

America is God's Crucible, the great Melting Pot where all the races of Europe are melting and re-forming! ... A fig for your feuds and vendettas! ... God is making the American (Zangwill 2016, p. 37).

How the great Alchemist melts and fuses them with his purging flame! Here they all unite to build the Republic of Man and the Kingdom of God. Ah, Vera, what is the glory of Rome and Jerusalem where all the nations and races come to worship and look back, compared with the glory of America where all races and nations come to labour and look forward. (Zangwill 2016, p. 199)

David, the play's Russian-Jewish protagonist, who speaks these lines, was an aspiring composer, writing a symphony about America as the great melting pot of humanity.

But if The Melting Pot glorified the potential of American assimilation over the fears and prejudices of American nativists, it actually left Jewish intellectuals (and others who championed the preservation of select forms of immigrant cultures) decidedly ambivalent. Zangwill's play drives the challenge home in focusing the play on the immigrant group he knew best. The play ends with David set to marry Vera, the humane and loving Christian—and the daughter, no less, of the Russian Baron who had oversaw the pogrom that killed David's parents.

Those Jewish leaders, therefore, who criticized Zangwill's celebration of assimilation accused him of misunderstanding the possibilities of Jewish survival in America, and especially the potential for Jews to marry each other. The response of Rabbi Judah L. Magnes, the prominent Reform rabbi in a high-profile, wealthy Manhattan congregation, as well as a leading Zionist figure, can serve as an example. He delivered a sermon about the play in 1909 (Magnes 1982). Magnes was decidedly more of a cultural nationalist than his congregants (and more so than nearly all reform rabbis in 1909), and in 1908, partly because of his views, he was named head of the newly founded New York Jewish communal governing board, the Kehillah; but the sermon reflects how much was at stake for Americans and American Jews in connection with Zangwill's play.

Magnes saw the trends Zangwill celebrated as group suicide, for religions, cultures and "nationalities". Fortunately, he consoled his congregation, Zangwill mistook the part for the whole. "Side by side with this process of Jewish decay, there is the process of Jewish awakening", a rebirth in self-identity, nationality, religion and Jewish education, a revival of the Hebrew language and "above all" a revivifying Jewish settlement in the ancient homeland of Palestine (Magnes 1982, p. 103). 
Regarding the broader American context, Magnes's sermon held up an alternative to the melting pot image. "A republic of nationalities" was a richer vision for an American future. "Each man as he strikes root here is no more obliged to yield his individuality, his race, his speech, his culture, his ideals, than he is obliged to yield his religion" (Magnes 1982, p. 104).

Magnes, and indeed Zangwill, Kallen and Wolfson, referred regularly to "nationality", so it will be helpful to distinguish two usages of the term in the English language a century ago. Its more common meaning referred to citizenship; its less common meaning to what we might call today peoplehood, or ethnicity (an historical origin group, or membership in one). However, in Central- and Eastern European languages the second meaning was the more common one. This second meaning also tended to come up in American discussions of assimilation and persistence of immigrant cultures. For some, nationality, in this second meaning, could have a biological component that was believed to influence character, like race; nevertheless, the biological element generally was emphasized less in connection with nationality than with race. Moreover, race itself was a term that could have cultural as well as biological transmission associated with it, as in Magnes's usage above (Perlmann 2018, pp. 150-58, 190).

Magnes noted that Zangwill was a Zionist, "believing in the creation of a national home for the Jewish nation". The play could celebrate "with such brutal frankness the destruction of Judaism in America" partly because Zangwill assumed that those unwilling to accept that assimilation could settle in the national homeland. But Magnes comments that this view was "rather a backward form" of Zionism. Much better to see in a national homeland a source of especially intense cultural energy and creativity for Jewish culture and religious values but not the only site in which Jewishness could persist (Magnes 1982, p. 105).

This notion of a vibrant re-energizing national center in Palestine interacting with a Jewish diaspora Magnes, like so many others, took from the influential Zionist writer Achad Haam. While Theodore Herzl had stressed the ingathering of Jews in a new state, Ahad Haam argued that such a project would never close down the large Jewish presence in the diaspora. Moreover, the ingathering would be both unlikely and pointless without a renaissance of Jewish cultural life. In the fullness of time, the Jewish independent homeland would provide the necessary cultural center that would continuously energize diasporic Jewish communities around Europe and in the new world (Zipperstein 1993).

Magnes's 1909 sermon is remarkable for predating the better-known formulations of Horace Kallen (Kallen 1915), and it is especially useful for us because it reflects the range of issues swirling around assimilation, the melting pot and a multinational America, especially for Jews. Nevertheless, few people probably knew about the sermon (it is unclear whether Wolfson, Hurwitz or Kallen did). ${ }^{3}$ But six years later, the last of these would himself publish an influential essay on some of the same themes in The Nation: "Democracy Versus the Melting Pot" (Kallen 1915). Kallen, too, saw Zangwill's celebration of the melting pot as a decidedly unattractive option for America. And Kallen too thought a "democracy" of nationalities a fuller and more attractive American Commonwealth than the melting pot.

Its form is that of the Federal republic; its substance a democracy of nationalities, cooperating voluntarily and autonomously in the enterprise of self-realization through the perfection of men according to their kind. The common language of the commonwealth, the language of its great political tradition, is English, but each nationality expresses its emotional and voluntary life in its own language, in its own inevitable Esthetic and intellectual forms. The common life of the commonwealth is politico-economic, and serves as the foundation and background for the realization of the distinctive individuality of each natio that composes it. Thus "American civilization" may come to mean ... a multiplicity in a unity, an orchestration 'of mankind.

3 The sermon had appeared in a journal published by Magnes's temple (Goren 1982, p. 523). 
As in an orchestra, every type of instrument has its specific timbre and tonality, founded in its substance and form; as every type has its appropriate theme and melody in the whole symphony, so in society each ethnic group is the natural instrument, its spirit and culture are its theme and melody, and the harmony and dissonances and discords of them all make the symphony of' civilization. (Kallen 1915) ${ }^{4}$

But Kallen took one further step that made it easier to have confidence in the persistence of group cultures over assimilation that a "democracy of nationalities" would require. He argued quite explicitly that the persistence of nationalities was a likely outcome because the distinctions among these nationalities rested on a biological (racial) foundation. It was for this reason that Kallen famously announced—-twice in the course of that essay—-that men could not change their grandfathers. ${ }^{5}$

Kallen's essay was not written for a specifically Jewish audience, and consequently did not discuss the Jewish case particularly fully, as Magnes had done. Nevertheless, Kallen, like Magnes, was very much involved in just such questions and elsewhere he too drew on Ahad Haam's vision of a Jewish center revitalizing the Jewish diasporic communities.

These, then, were the issues Hurwitz had in mind in writing to Wolfson some two and a half years after Kallen's essay appeared. Hurwitz, recall, wanted to take up "the general subject of 'Democracy and the Melting Pot' with particular reference to the place of the Jew in the American Commonwealth". It would be "a valuable stimulant to thinking on the whole question, both for Jews and for non-Jews".

Kallen had been a few years ahead of Wolfson at Harvard and served as something of an older, more Americanized, mentor for a number of years. However, by 1918 Kallen was in Madison, Wisconsin and Wolfson had been at Harvard for a decade. Still, the two corresponded and met not infrequently. But a close reading of the "Pomegranates" essay shows how completely Wolfson rejected Kallen's (and Magnes's) view of the American ethnic future. He would argue that Kallen's vision was both unrealistic and less desirable from an ethical standpoint.

\section{The First Installment of "Pomegranates" (February 1918)}

It is this rejection of "Multi-National America", along with Wolfson's determined emphasis on the religious and not the national features of Jewish life in America that is so striking. Wolfson was hardly the elite American insensitive to immigrant claims for cultural autonomy and persistence. He understood those claims but decisively rejected them. Yet he insisted that American Judaism could survive on another basis, preserving what was most important in the Jewish legacy.

The crucial Section 5 in the first part of "Pomegranates" ("Zionism and Multi-National America") begins with a bitter attack on "Our Yiddish kinsmen" for having been "the first among us to be taken in by that nefarious propaganda which has for its ultimate aim the complete Austrianization of America" (Wolfson 1918, p. 20). Why "Austrianization?" Because the Austro-Hungarian Empire was the clearest example of a multi-national empire, in which ethnic division, jealousy and competition were destructive.

Have been prating for some time about the tyranny of the American Public School, which forces upon our children the knowledge of a foreign language-English. They [criticize] ... our government [as it] refuses to recognize the rights of the many small nationalities within its own borders. They hold up the schools of some Middle-Western cities, where German forms part of the curriculum, as the ideal schools for cosmopolitan American cities; and they [would emulate] the constant frettings of the French-Canadians in Canada. (Wolfson 1918, pp. 20-21)

4 The striking anticipation of Kallen's views in Magnes's sermon extends also to the conclusion of each with the symphony metaphor (Magnes 1982, p. 106).

5 Kallen also believed that the geographic concentration of different peoples across America would undergird a multi-national America (Kallen 1915). 
Worse yet, among American Jews, it is not just the Yiddishists who are moving in this "nefarious" direction.

Of late, some of our Zionists, not to be outshone by their Yiddish rivals, have fallen in with the same trend of thought. No longer is Palestine to be the only home for the rejuvenated Jewish nationality, but the Jews are to insist on national recognition everywhere they happen to live. (Wolfson 1918, p. 21)

This emphasis on "national rights" for minorities "everywhere" was just then (1916-1918) emerging in the efforts to claim protections for the Jews and others in postwar arrangements under the rubric of "national minority rights". Moreover, it was an energizing force behind the efforts to organize an "American Jewish Congress". The democratic organizing principle of the Congress-all Jews could vote for the "Congress" and its deliberations would be public was a direct challenge to the elitist American Jewish Committee. The Committee, founded in 1906, had quickly seized a place among the most influential American Jewish organizations. But it was led by a self-recruiting elite board that was most comfortable working behind the scenes (Perlmann 2018, pp. 150-58, 186-90).

It is possible that here again Wolfson found a reason to be exasperated with the claims to democratic rather than elite guidance (and especially so given the numerical dominance of Yiddish-speaking immigrants).

In any case, Wolfson left no doubt that there were broader reasons why he saw any call for national minority rights in the American context as benighted. His reasoning drew on his understanding of America, and not on a specifically Jewish perspective. This approach was already noticeable in the passages quoted above, but he drove the point home in a self-conscious argument that prioritized the broader American reality.

There is a general aspect to this problem [i.e.,: multi-national America] which touches the very existence and destiny of this country in the future. It largely depends upon the way of thinking, and willing, and believing of men of the present generation whether this country, with its heterogeneous population, will emerge in the end of days as a distinct nationality, one and homogeneous, or will continue to be the unfused scrap-heap that it now is. From a general human point of view, there can be no denial that it would be more desirable to have in this country a new composite national civilization, the result of fusion, rather than a million of parochial schools and as many quaint outlandish cook shops. (Wolfson 1918, p. 21)

Wolfson drew the implications with a nod to the melting pot. ${ }^{6}$ The imagery in the following passage gets a bit convoluted; the "[thoroughgoing] mixture" is the more homogeneous, the "[unmolten] compound" the less so.

For let us not deceive ourselves, a multi-national America would not amount to more than that [i.e.,: an unfused scrap heap]. It is hard for anyone to be carried away by that pious alarm of those ingenious advocates of the scrap-heap theory over the impending loss of the excellent old-world qualities of the foreign-born while passing through the melting-pot. Such of those old-world qualities as are really excellent and fit for survival will be saved and preserved in a thoroughgoing national mixture in a much more refined form than they would in an unmolten national compound. (Wolfson 1918, p. 21)

Zangwill had, in fact, already stressed (as Wolfson did here) that the best of each people would be preserved in the melting process. Perhaps by stressing this feature, Wolfson expressed himself vaguely

6 It is worth noting that's rejection of a multinational America (in both parts of his essay) did not explicitly limit itself to immigrants let alone to European immigrants. But he also never mentioned African Americans or non-white immigrants. Zangwill's Melting Pot itself was likewise heavily focused on the European immigrants, even if the published version of the play did include a cursory mention of other groups. A plausible interpretation would be that Wolfson was agnostic as to how nonwhite races would fare in the creation of "a distinct nationality". 
enough to avoid alienating at least some who, like Kallen and Magnes, envisioned a multi-national America. And in the context of the angry attack on "the Yidds", his critique of the Kallen position, seems to have been missed by many (Hurwitz 1918). ${ }^{7}$

In any case, within this embrace of an America with "a distinct nationality, one and homogeneous", Wolfson proceeded to the "specifically Jewish aspects of the problem". If he rejected Kallen's and Magnes's "Multi-National Americanism", what could he do with Zangwill's vision of a complete Jewish assimilation? Everything depended on the nature of Jewish national solidarity, and the proper understanding of how Zionism would transform it. Hence the section title, "Zionism and Multi-National Americanism". He had already ruled out the latter; the success of the former would eventually pry apart the national and religious aspects of Jewish life.

If at the present time Zionism preaches Jewish national solidarity in the diasporas as something distinct from Jewish religious unity, it is only a temporary measure ... On the morrow of our restoration, the moral duty of national loyalty will be lifted from the individual Jew. Then it will be each for himself. Then, indeed, to be a Jew in the diaspora will mean nothing more than the confession of a certain religious creed. Zionism is thus striving not only for the establishment of a Jewish nationality, but also for facilitating the complete and harmonious assimilation, in a cultural and political sense, of the Jews living in the diaspora. (Wolfson 1918, p. 22)

Thus, like Zangwill, he could embrace both Zionism (for Palestine Jews) and a single, unified nationality in America, in which Jews would take part; and like Magnes and Kallen, he could embrace the continued indefinite existence of Judaism in America. He enthusiastically supported the Zionist enterprise and a Hebraist understanding that what ultimately mattered in the Jewish historical legacy. But in the diaspora that legacy would eventually be embodied exclusively in "a religious creed". Unlike Zangwill, Magnes or Kallen, he insisted that it could indeed thrive in America once Zionism's success in Palestine made "complete and harmonious assimilation in a cultural and political sense" easy for Jews in the United States. Then-current Reform Jewish dogma also supported a Jewish religious continuity. But Reform generally rejected the modern Zionist movement because the latter seemed to threaten the notion of Jewishness as religion.

\section{The Second Installment of "Pomegranates" (June 1918)}

Because the essay was composed of relatively short, loosely related sections, Wolfson was able to revisit broad themes from new angles without seeming to repeat himself. The remarkable section that began the second part was titled "The Cephalic Index and Baseball" (Wolfson 1918, pp. 162-63).

The cephalic index was the measure physical anthropologists and others used to assess head size and shape. Its significance for theories of racial persistence and change had to do with the assumption that head shape was a skeletal feature very resistant to change, even over many generations. But then, in 1910, Franz Boas published a study of New York City children from various immigrant backgrounds. Boas found that the cephalic indices of the children, raised in the American environment, did not differ at all as much as those of their immigrant parents. The study thus suggested that even human skull shape was very sensitive to environmental effects. Further, if environment was so influential in regard to this slowest-changing skeletal feature, how much more influential must be environmental influences upon character and values! All in all, Boas's article seemed to strike a sharp blow against the notion that immigrant groups differed on racial grounds in ways that would impede assimilation (Boas 1911).

7 Apparently there was no defensive response from Kallen himself in connection with the critique of "Multi-National America". Evidence of how easily the critique of Kallen could be missed is seen in a report of an acquaintance to Hurwitz that "Some are inclined to think that Kallen is the author; they do not seem to realize that Chapter 5 [i.e.,: "Zionism and Multi-National America"] is an assault on Kallen's position" (Hurwitz 1918). 
Wolfson obviously knew about the Boas study. Apparently he believed that his readers knew it too, since he merely referred to the cephalic index in passing, without defining it or mentioning Boas; he mentioned the study only in a single subordinate clause. But he made it clear that readers would be foolish to rely on race to understand how long the cultures of distinct immigrant peoples would persist in the United States.

Wolfson noted that race (meaning here a physical source of group cultural persistence) cannot be proven to be negligible, but that it might well be so. In any case, in understanding social and intellectual life, race is trivial and "religion", meaning any firmly held belief or value, is consequential (Wolfson 1918, p. 162). Wolfson also contrasted "nationality" with race. Whatever the range of ways that others might relate nationality and the biological transmission of cultures, Wolfson surely meant to move biological heredity as far as possible from his sense of nationality. Indeed, he observed in passing that German nationalism had gone astray in confusing race and nationality-as had the nationalism of the "Yidds". But for him,

Nationality is purely a subjective group ... It is for this reason that nations may survive their loss of country and king provided they can preserve their ideal-hence Themistocles' exclamation: "Athens is burned, Athens is in our ships". The unity which makes for nationality is ... a dynamic, vital principle by which men consciously act together. (Wolfson 1918, p. 163)

The complex but elegant sentence that closes "The Cephalic Index and Baseball" draws together the broad themes that he had in mind by reference to the index-baseball, race, nationality, conscious loyalty to a group and the assimilation of "the descendants of the diverse nationalities in this country".

Those who see the possibility of the future rise of an American nation in the fact that recent skull measurements have shown that the descendants of various races in this country tend to approach to a uniform cephalic index will have more reason to be hopeful when it will have been shown that the descendants of the diverse nationalities in this country all learn to chew gum, to drink ice water, to play ball, and to venerate the Constitution of the United States. (Wolfson 1918, p. 163)

He then relied on the distinctions he had drawn between race, nationality and religion in order to explicitly reject Kallen's arguments for a multi-national America. Without Kallen's belief in a biological basis for cultural continuity ("you cannot change your grandfather"), baseball could be relied on to trounce pre-immigration culture.

Modern Jewish nationalism rests its case on the assumption of the indestructibility of race and the inefficacy of assimilation. The Jews are still a nation, it says, because Judaism is not a religion but a set of inherited characteristics, and character, like fate that it is, cannot be shaken off at will nor melt away in the crucible [i.e.,: in Zangwill's Melting Pot]. Or, to put it in the words of our own Doctor Kallen, you may change your religion, but you cannot change your grandfather. As a result of this view, modern Jewish nationalism, setting out to prove the existence of a Jewish nationality, returns with a doctrine of pan-Jewish nationality. It is well-nigh half a century that we have been urging this doctrine of pan-Jewish nationalism. So scandalously false is it that it has almost shocked the world into accepting it as true. (Wolfson 1918, p. 163)

The issue, Wolfson stresses, is not whether you can change your grandfather but your patrimony. Whatever minimal elements of race might conceivably exist and exert and influence on Jewish minds, they surely do not amount to a Jewish religion, universal among everyone descended from a Jewish grandfather. "To prove pan-Jewism, we must not point to an unchangeable grandfather, but rather to a 
common patrimony, and of this patrimony, we know, many of us have either squandered their share or bartered it away" (Wolfson 1918, p. 163). ${ }^{8}$

The living Jewish tradition ... does not come down from one generation to another automatically by mere natural heredity. It comes down only through social transmission ... It must be revealed to and acquired anew by each successive generation. It is something perishable and forgettable and can be preserved only by studying it, by practicing it. (Wolfson 1918, p. 167-68)

Wolfson also strongly criticized Judah Magnes for viewing "the Yidds" as the "living Jewish People,' 'through whom the tradition of Judaism still courses and lives.'” Thus for Wolfson, both Kallen and Magnes found meaningful historical continuities for Judaism where there were none-Kallen by reliance on racial dynamics, Magnes by reliance on the ghettoized isolation of the Yiddish masses (Wolfson 1918, pp. 165-67).

Having kicked out the racial and ghetto underpinnings of a supposed "multi-national America" and of "pan-Jewism", Wolfson approached anew the future of American Judaism, this time stressing explicitly how much his conception owes to the concepts of Reform Judaism. He provocatively titled the relevant section "of the Jewish Persuasion-The Restatement of a Truth", a title that could not help but remind the reader of the expression often used to capture the Reform Jewish self-image as citizens of a country who were "of the Jewish Persuasion". And lest the reader think he was satirizing the usage, Wolfson began,

One thing we should now have the courage to admit, namely, that for over a century, ever since the emancipation of the Jews in Western Europe, Judaism has ceased to be a national religion and has become a universal church". (Wolfson 1918, p. 164)

The concept of Judaism as a universal church flew in the face not only of a racial understanding of Jewish cultural unity but also of most Zionist understandings. The latter had that condemned the Reform description because it was meant to reject a Jewish national existence. But the Zionist condemnation has been a mistake. The reality was "not that any number of those nationalities [i.e.,: Germans, Englishmen, Hungarians, and members of many other nationalities"] have become converted to Judaism, but that a great number of former Jewish nationals have become assimilated into those nationalities, which, after all, amounts to the same result". Consequently,

The phrase "Germans of the Jewish persuasion", "Englishmen of the Jewish persuasion", and the many other Europeans of the Jewish persuasion, so often ridiculed and gibed at by us Zionists, is a true description of a real fact and not a mere euphemism for a luckless plight. (Wolfson 1918, pp. 164-65)

However, the situation was different in eastern Europe "where the Jews had no opportunity to assimilate themselves and where consequently they succeeded in maintaining their national identity" (Wolfson 1918, p. 165). By extension, this description also applied to the mass of eastern-European-Jewish immigrants who had arrived in America. Nevertheless, Wolfson insisted that the split between nationality and religion also emerged in the eastern-European context. That was because the religious and national elements of Jewishness formerly "coextensive" were so no longer: the nature of nationality had been modernized by secular ideologies.

To those national Jews, too, Judaism become a church, for the Jewish religion was no longer co-extensive with their Jewish nationality. Their nationality was based on a newly developed secular Jewish culture, on purely national ideals, aspirations and interests which were quite

8 Wolfson was no doubt among the first to reject Kallen's reliance on biological transmission. I. B. Berkson and Julius Drachsler would do so a few years later (Perlmann 2018, pp. 286-87). 
apart from their purely religious interests. They were Jews of the Jewish persuasion. (Wolfson 1918, p. 165)

Once again, then, for Wolfson it is through Zionism, the ideology of modern Jewish nationalism, that diasporic Jewishness-especially but not exclusively in the United States-was evolving even then towards "a universal church", evolving towards the vision of the Reform movement: a purely religious existence in the diasporic communities (even as Reform itself often denied the legitimacy of the Jewish national movement). After the creation of the national center in Palestine, the "Jews of the Jewish persuasion" just mentioned will typify the outlook of the center, and they will relate to the diasporic communities on the basis of that "Jewish persuasion".

In a reconstructed world after the war, where political freedom will everywhere enable the process of assimilation to take effect... what is going to be the common bond of union, supposing that such a bond will exist, between the reconstituted Jewish nation in Palestine and the Jews outside of Palestine? Is it not the church idea of Judaism, a spiritual church without any temporal power, appealing to each Jew as an individual, to his individual soul, without attempting to interfere in his political and national allegiance? (Wolfson 1918, p. 165)

Of course, he remained anxious about "the Yidds'" claim to take over the Zionist project. But even this threat could now be couched in the terminology of the emerging split between modern nationalism and Judaism as a universal church. "I can even imagine the future possibility of Yidds of the Jewish persuasion, should the Yidds succeed" in gaining "some measure of national autonomy" in postwar East Central Europe (Wolfson 1918, p. 165).

This discussion of national vs. religious adherence and of the coming Jewish universal church-notwithstanding that it is expressed by an ardent supporter of Zionism and a quintessential eastern-European Jewish immigrant-involves a striking number of admissions that the eastern-European Jews in general and the Zionists in particular must take Reform Judaism much more seriously than they ever had done.

It is well-nigh half a century that we have been urging this doctrine of pan-Jewish nationalism. So scandalously false is it that it has almost shocked the world into accepting it as true.

One thing we should now have the courage to admit, namely, that for over a century, ever since the emancipation of the Jews in Western Europe, Judaism has ceased to be a national religion and has become a universal church.

The phrase "Germans of the Jewish persuasion" ... so often ridiculed and gibed at by us Zionists, is a true description ... and not a mere euphemism for a luckless plight.

It behooves us Zionists now to recognize the just contention of our coreligionists of Western Europe and of their descendants in this country as to the church conception of Judaism, even as they are now gradually coming to recognize the existence of Jews of the Jewish persuasion. (Wolfson 1918, p. 163-65)

If indeed "the living Jewish tradition ... comes down only through social transmission ... and acquired anew by each successive generation", where did Wolfson find the sources for hope that this process of transmission would indeed continue? Like many such efforts, Wolfson's "Pomegranates" is long on criticism and short on examples for hope. Nevertheless, near the end of the essay Wolfson shifted, if only briefly and lyrically, to the signs for hope. These are found first of all in schooling, worship and home life,

wherever the Torah is studied, from the pietist Kneset Bet Israel of Slabodka to the most radical school of Cincinnati ... wherever Jews congregate to worship their God, from the gabled wooden synagogues in Lithuanian townlets to the cruciform marble temples in the fashionable quarters of American cities ... where Jewish lives are lived, from the hut of the 
Polish Chasid where religious ceremonies are rigorously observed with all their cabalistic symbolisms, to the palatial residences of the wealthy American Jews where faint mementos of Judaism are seasonably tolerated for their symbolic suggestiveness. (Wolfson 1918, p 168)

The fourth and last feature that Wolfson heralded as the living Jewish tradition, indeed its "most exalted expression" was "the modern Hebrew literature - that wonderful literature that breathes from its pages whatever is sublime and noble in the time-honored Jewish tradition" (Wolfson 1918, p. 168). This range of signs for hope in future for Judaism contrasts with what defines "the Yidds, whose "life's vision is warped by the sordid aims of soulless materialism and whose spirit is fed on ignorance ..." (Wolfson 1918, p. 168).

\section{Concluding Remarks}

From the perspective of our own time, the essay stimulates nagging questions, and the brief references to these four sources of hope for a creative "universal Jewish church" can hardly resolve them. Notice first that the last of these sources of hope for the future, "that wonderful modern Hebrew literature" is claimed as a source for Americans "of the Jewish persuasion". Yet in the first part of "Pomegranates", Wolfson had explicitly envisioned the eventual "complete and harmonious assimilation, in a cultural and political sense, of the Jews living in the diaspora". Could Hebrew literature really help stimulate Judaism as a universal church? Should it not be considered more naturally as the expression of the Jewish "nationality" whose homeland would be built up in Palestine? Perhaps we should see in Wolfson's invocation of modern Hebrew literature an indication of how broadly he understood the domains of religious culture and literature (no doubt he meant more than imaginative literature). And perhaps Wolfson simply meant that prior to the creation of an independent center in Palestine, even the Hebraic elements in the national culture would serve to stimulate the future American Jewish church. But in the absence of any clarification, we are left to wonder; for surely the simplest classification would have placed "modern Hebrew literature" with nationality rather than with the American Jewish universal church.

And if the role of modern Hebrew literature seems unsettled in the American future, how much potential can really be found in the other three sources of hope-school, worship and home life? To put it in the terms he had used in rejecting "multinational America": how would long could these institutions resist the American dynamics of assimilation, so forcefully described in connection with "The Cephalic Index and Baseball"?

Finally, what are we to make of his re-evaluation of Reform? On the one hand, we have seen the many acknowledgements that "we" - east-European Jews and Zionists—had badly misjudged its accomplishments. Elsewhere, he explicitly compared the achievements of Reform's early nineteenth century thinkers with the twelfth century Maimonidean synthesis. Both movements sought a creative adjustment of the Jewish religious heritage with then-contemporary advances in thought (Wolfson 1921, pp. 76-77, 81). ${ }^{10}$

And yet, Wolfson hardly ignored the movement's failings, as even the long passage on sources of hope just quoted shows: "cruciform marble temples", and "palatial residences ... where faint mementos of Judaism are seasonably tolerated". The Reform movement of the nineteenth and twentieth centuries had been too willing to abandon elements of prayer and ritual that retained the potential to

9 Possibly such questions had something to do his abandonment of opinion pieces on current issues by 1925. But other possible explanations are plentiful enough. Most obvious was the increasing likelihood that he would find a tenured perch, at Harvard or elsewhere, and the emergence of his giant research agenda. Nor would he have wanted to endanger chances for a secure position. A supportive senior colleague apparently warned him in 1918, "Be careful or you'll become a successful journalist" (Schwarz 1978, p. 69). Also, Wolfson played a notable role in the 1922-1923 debates at Harvard over Jewish enrollment quotas (Synnott 2013); that involvement may have left him skeptical about such expenditures of time and effort. Finally, the establishment of his Harvard chair made him feel responsible for its success (Schwarz 1978, p. 80).

10 In "Escaping Judaism" (Wolfson 1921), Wolfson abandoned, without comment, his earlier description of the future diasporic Judaism in terms of a "universal church". 
bind the individual emotionally to the tradition, it had stressed Jews' mission to the gentiles instead of their own need for spiritual revitalization, and its later leaders had allowed the early creativity of the movement to ossify (Wolfson 1918, pp. 80-82, 165-68). ${ }^{11}$ How hopeful, then, could Wolfson have been that in the long run the promise of ongoing reformation in the Jewish "universal church" would be adequate to withstand a more thorough-going assimilation?

The most likely response he would have made to such questions about assimilation, I think, is that in every generation some Jews had abandoned Judaism, and that one could only hope that many more Jews would not do so. Second, it is crucial to recall that Wolfson's great concerns here had to do with "nationality" and its relationship to the true historical legacy of Judaism; this was the the approach he took to Hurwitz's initial invitation to reflect upon the options of Zionism and multi-national America. Zionism, he hoped, was creating a homeland for the Jewish nationality, and for all he knew the Yidds might be creating another nationality. But Jews living in enlightened states would surely come to adopt the nationalities of the states in which they lived. That was the meaning of the cultural and political assimilation he foresaw for them, and the reason he could have no faith in Magnes's and Kallen's multi-national America (even if he had wanted such faith, which he did not). A Jewish nationality would not unite the world's Jews but Judaism would unite them, insofar as anything would. Judaism would be the basis on which Jewsof different nationalities - in the spiritual center, those in diasporic communities and maybe even the Yidds - would relate to each other in the future. Just how strong a bond that faith would provide was a separate question, and not his dominant theme in "Pomegranates".

But it is also important to appreciate here some of the great historical differences between his time and ours. In particular, the Jewish center in Palestine was only just beginning its cultural rise and a generation would pass before it achieved political independence. Consequently, the character of future interactions between that center and the American Jewish diaspora-how the former would actually "revitalize" the latter-was as yet all conjecture. Also other forces could still be expected to influence American Jewish life through the replenishment of immigrant culture-for example from the "pietist Kneset Bet Israel of Slabodka" and the "hut of the Polish Chasid where religious ceremonies are rigorously observed with all their cabalistic symbolisms". But the influence of these forces would soon be far weaker than Wolfson could have reasonably supposed in 1918, first (for American Judaism) through the American immigration quotas of 1921 and 1924 and then through the Holocaust. ${ }^{12}$

Funding: This research received no external funding.

Conflicts of Interest: The author declares no conflicts of interest.

\section{References}

Boas, Franz. 1911. Changes in Bodily Form of Descendants of Immigrants. United States Immigration Commission, Reports 38. Washington: Government Printing Office.

Cohen, Steven M., and Arnold M. Eisen. 2000. The Jew Within: Self, Family and Community in America. Bloomington: Indiana University Press, ISBN 0253337828.

Feuer, Lewis S. 1976. Recollections of Harry Austryn Wolfson. American Jewish Archives 28: 25-50.

Glazer, Nathan. 1989. American Judaism, 2nd ed. Chicago: University of Chicago Press, ISBN 0226298434.

Goldberg, Hillel. 1989. Between Berlin and Slobodka: Jewish Transition Figures from Eastern Europe. Hoboken: Ktav Publishing House, ISBN 0881251429.

Goren, Arthur A., ed. 1982. Dissenter in Zion: From the Writings of Judah L. Magnes. Cambridge: Harvard University Press, ISBN 0674212835.

11 Intriguingly, given these critiques, he made no mention in either essay of the American Conservative movement, then developing through the Jewish Theological Seminary in New York City.

12 Nor could he have foreseen, on the other side of the ledger, the revitalization American Orthodoxy in spiritual and demographic terms, energized in part by migrations after the Holocaust. 
Greene, Daniel. 2011. The Jewish Origins of Cultural Pluralism: The Menorah Association and American Diversity. Bloomington: Indiana University Press, ISBN 0881251429.

Higham, John. 1955. Strangers in the Land: Patterns of American Nativism, 1860-1925. New Brunswick: Rutgers University Press, B000GYOSEO.

Hurwitz, Henry. 1917a. Letter to H. A. Wolfson. In Hurwitz Papers. Cincinnati: American Jewish Archives, July 10. Hurwitz, Henry. 1917b. Letter to H. A. Wolfson. In Hurwitz Papers. Cincinnati: American Jewish Archives, November 12.

Hurwitz, Henry. 1917c. Letter to H. A. Wolfson. In Hurwitz Papers. Cincinnati: American Jewish Archives, November 21.

Hurwitz, Henry. 1918. Letter to H. A. Wolfson. In Wolfson Papers. Cambridge: Harvard University Archives, HUGHP (58.7) Box 3. February 27.

Kallen, Horace M. 1915. Democracy versus the Melting Pot. The Nation, February 18 and 25.

Kallen, Horace M. 1918. Letter to H. A. Wolfson. In Wolfson Papers. Cambridge: Harvard University Archives, HUGHP (58.7) Box 2. February 19.

Klingenstein, Suzanne. 1991. Jews in the American Academy, 1900-1940: The Dynamics of Intellectual Assimilation. New Haven: Yale University Press, ISBN 0300049412.

Magnes, Judah L. 1982. Sermon Delivered at Temple Emanuel, New York, October 9, 1909. In Dissenter in Zion: From the Writings of Judah L. Magnes. Edited by Arthur A. Goren. Cambridge: Harvard University Press, pp. 101-6.

Perlmann, Joel. 2018. America Classifies the Immigrants: From Ellis Island to the 2020 Census. Cambridge: Harvard University Press, ISBN 0674425057.

Schwarz, Leo W. 1978. Wolfson of Harvard: Portrait of a Scholar. Philadelphia: Jewish Publication Society, ISBN 0827600984.

Shenker, Israel. 1972. Harvard's Resident Sage Marks 85th Birthday Today. New York Times, November 2, 45.

Sklare, Marshall. 1955. Conservative Judaism: An American Religious Movement. Glencoe: Free Press, ASIN B000FM87I0.

Synnott, Marcia Graham. 2013. The Half-Opened Door: Discrimination and Admissions at Harvard, Yale and Princeton, 1900-1970, 2nd ed. New Brunswick: Transaction Printing, ISBN 1412813344.

Twersky, Isadore. 1978. Harry Austryn Wolfson: in Appreciation. In Wolfson of Harvard. Edited by Leo W. Schwarz. Philadelphia: Jewish Publication Society of America, pp. xiii-xxvii.

Wertheimer, Jack. 2018. The New American Judaism: How Jews Practice their Religion Today. Princeton: Princeton University Press, ISBN 0691181292.

Wieseltier, Leon. 1976. Philosophy, Religion and Harry Wolfson. Commentary 61: 57.

Wolfson, Harry Austryn. 1917a. Letter to Henry Hurwitz. In Hurwitz Papers. Cincinnati: American Jewish Archives, July 10.

Wolfson, Harry Austryn. 1917b. Letters to Henry Hurwitz. In Hurwitz Papers. Cincinnati: American Jewish Archives, October 17, 19, 26 and 31.

Wolfson, Harry Austryn. 1917c. Letter to Henry Hurwitz. In Hurwitz Papers. Cincinnati: American Jewish Archives, November 22.

Wolfson, Harry Austryn. 1918. Pomegrantes. Menorah Journal 4: 16-170.

Wolfson, Harry Austryn. 1921. Escaping Judaism. Menorah Journal 7: 71-168.

Zangwill, Israel. 2016. The Melting Pot, reprint ed. Scotts Valley: CreateSpace Independent Publishing Platform, ISBN 1537210793.

Zipperstein, Steven J. 1993. Elusive Prophet: Ahad Ha'am and the Origins of Zionism; Berkeley: University of California Press, ASIN B0093NC76U.

Zolberg, Aristide R. 2006. A Nation by Design: Immigration Policy in the Fashioning of America. Cambridge: Harvard University Press and the Russell Sage Foundation, ISBN 0674030749.

(C) 2018 by the author. Licensee MDPI, Basel, Switzerland. This article is an open access article distributed under the terms and conditions of the Creative Commons Attribution (CC BY) license (http:/ / creativecommons.org/licenses/by/4.0/). 